\title{
Clinton struggles to appease all sides over climate proposals
}

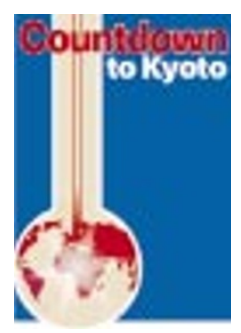

[WASHINGTON] US President Bill Clinton sought last week to bridge the yawning gap between two audiences for his climate change policy - the international community and the US Senate - by doing what he does best, and offering a vague compromise designed to appease both groups.

On the face of it he failed: Clinton's proposal to reduce greenhouse gas emissions to 1990 levels by 2008-12 managed to attract sharp criticism from senior European officials and prominent senators, as well as the main environmental and industrial groups. But politically he may yet succeed in the classic Clinton manner - by occupying the hallowed middle ground on the issue, and leaving the difficult choices to his successors.

There are two key elements to the sketchy domestic policy proposal delivered by the president on 22 October. One is an early action plan, which includes some incentives to cut greenhouse gases but which largely relies on voluntary actions to cut emissions.

The second is an emissions 'trading scheme', ill-defined at this stage but probably international in scope and based on a successful US experiment in trading sulphur dioxide emissions, to take effect in 2008.

The success of the former element will depend on faith in the latter. "It's difficult to see how the early action plan is different from the existing voluntary arrangements," says one congressional staff member. The difference ought to be that when the trading regime arrives in 2008, polluters will receive credits for cuts they make now. But, as the staff member puts it, "politics being politics, they might choose to do nothing and lobby like hell" against the trading scheme actually being implemented in 2008 .

Clinton administration officials seem to concede that tough choices will be left to others. "Each Congress is going to look at what's working and what's not working," says Gene Sperling, Clinton's chief economic adviser.

The incentives that Clinton will provide for voluntary action will be included in the 1999 budget (for the year beginning 1 October 1998), which he will present in February, Sperling says. The value of tax incentives and research and development spending amounts to $\$ 5$ billion over five years; a large sum, but not much in its potential impact on America’s $\$ 5,000$ billion-a-year economy.

The research and development package is likely to reflect a recent report from a panel of the President's Council of Advisors in Science and Technology chaired by John Holdren of Harvard University. Holdren called for an extra $\$ 1$ billion a year for energy research - only enough, he admits, to restore spending to its level of five years ago. Half the money would go to research on energy efficiency and the rest would be split between fusion, fission, coal and renewables. But the Republican-controlled Congress is likely to resist extra spending in these areas.

The other specific domestic action promised by Clinton is the restructuring of the electricity industry to enhance competition and cut carbon dioxide emissions. That, too, may be a tall order in the Congress, where legislation to deregulate the industry is likely to be drafted in a way that protects operators of existing coal-fired power plants.

But the main focus of attention at the conference of the climate convention in Kyoto, Japan, in December will fall on what the United States says it can achieve, rather than what it can actually deliver. In this regard, environmentalists were angry at a last-minute decision by the president to drop a pledge to cut emissions by 5 per cent by 2017. Carl Pope, president of the environmental group the Sierra Club, said he was particularly disappointed by that decision.

This retreat may leave the United States with some room for manoeuvre in the Kyoto negotiations. The United States may concede a little ground to the rest of the world on emission targets, in exchange for something that will satisfy its requirement that, as Clinton put it last week, "key developing nations meaningfully participate in this effort".

The concessions that the United States seeks include agreement by these countries

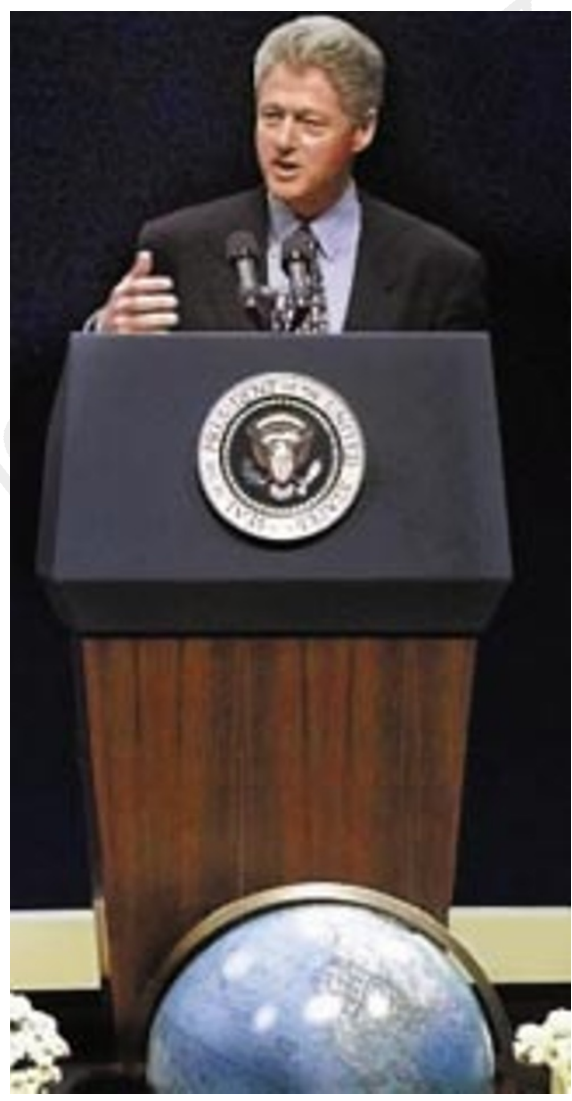

Clinton: may be able to leave difficult choices on carbon emissions to his political successors.

to participate in "joint implementation", which would allow rich countries to meet their targets by helping with emissions cuts in poor countries. Of the important players, only Argentina has so far agreed to this. Also anticipated in December is a 'Kyoto mandate' attached to the treaty, to bring developing countries into the process. Colin Macilwain

\section{A ustralia eases path to Kyoto agreement}

[LONDON] The British government has brokered a deal between Australia and developing countries in which Australia has agreed to drop its opposition to a greenhouse gas reduction protocol in return for a commitment to "significant reductions" from developing countries at a later date.

The deal was struck after a series of meetings between foreign ministry officials at the Commonwealth heads of government conference in Edinburgh, which ended on Monday (27 October).

But Australia's position remains ambiguous. Shortly after agreeing to the declaration, Prime Minister John Howard appeared on television claiming that the document amounted to a triumph for Australia, as it did not imply a commitment to legally binding emissions reductions.

Australia is opposed to these on the grounds that they would hurt the country's coal and electric power industries. It fears that jobs will be lost if Australia's power companies relocate to neighbouring SouthEast Asia to take advantage of more liberal rules on greenhouse gases.

Developing countries, on the other hand, do not want to reduce their emissions just yet. Some, such as India and China, are concerned about the possible adverse impact on their nascent industries. Others 
- believe that premature discussion of developing country obligations could detract from the main purpose of the Kyoto conference, at which developed countries are due to sign a legally binding emissions reduction protocol.

Climate change was not on the initial agenda of the Commonwealth conference. But British officials realized that the meeting would be an ideal occasion to try to generate consensus between Australia and other Commonwealth countries.

Another aim was to reduce the gap between developing countries and the United States, which confirmed last week that it will commit itself to a legally binding target to stabilize emissions at 1990 levels between 2008 and 2112, but only if there is 'meaningful participation' from key developing countries (see previous page). Argentina has in principle agreed. But other countries - including Brazil, China and India - so far remain opposed.

Environmentalist groups are also predictably angered, although their rhetoric has lacked some of its previous fire.

"President Clinton's watching a house starting to burn. He wants to do something about it, but chooses to pull out the garden hose when he really needs a water truck," says Jennifer Morgan of the US Climate Action Network, based in Washington DC.

Some groups were optimistically expecting the United States to announce slightly more ambitious targets - perhaps a reduction in emissions to below 1990 levels - but coupled to much tougher conditions. Others, however, were privately relieved that Clinton confirmed his commitment to a legally binding target, rather than "just do nothing".
Last week, the Group of 77 (G77) nations and China endorsed the European Union's target to reduce greenhouse gas emissions by 15 per cent by 2010 . One delegate from a major industrializing country says that this will remain the G77's "bottom line" position. Another developing country delegate says that the United States will have to make concessions if there is to be agreement at Kyoto.

The G77's endorsement of the European position was due to an agreement between the Alliance of Small Island States and oilexporting countries about the latter's demands for compensation for revenues lost as a result of the reduced demand for oil. Both groups of countries have now agreed to call for compensation for any country that suffers damage from the effects of either climate change or climate change policies.

Meanwhile, discussions this week in Bonn between the United States and developing countries - the last formal negotiations before Kyoto - have been making little headway. A two-day informal meeting before the start of the formal talks on 20 October resulted in deadlock.

Nonetheless, efforts to bring the US and developing country positions closer will continue during this week's visit to the United States by China's president Jiang Zemin. Three days of direct talks hosted by Japan are also scheduled in the second week of November.

Ehsan Masood
[BONN] The United Nations' advisory panel of climate scientists is to be expanded, and its procedures restructured, according to Bob Watson, the incoming chair of the

Intergovernmental Panel on Climate Change (PCC).

In future, the panel will include more scientists from developing countries and economies in transition, and business and development groups, Watson told the UN climate meeting in Bonn last week (see above). Reviews of scientific literature will also include material in languages other than English.
IPCC's Third Assessment Report on the world's climate, and a summary 'Synthesis' report for policymakers, will be ready by 2001 , he said. The main report will focus heavily on regional aspects of climate change, while the synthesis report will consider key policy-relevant topics. Proposed answers to these will be circulated to governments for comment before being approved by the IPCC.

The changes have been partly designed to reduce conflict between scientists representing governments and those belonging to independent research establishments. The previous second assessment report, particularly the summary document, was often surrounded by controversy (see Nature 378, 524; 1995).

Policymakers wanted answers to specific policyrelated questions in language they could understand.

But the scientists drafting the reports were reluctant to stray beyond the confines of science, whose findings were often uncertain or subject to debate, a position which confused policymakers. E.M.

\section{Controversy flares over A IDS prevention trials in third w orld}

[WASHINGTON] A furious exchange between researchers at Johns Hopkins University (JHU) and public health advocates, carried out in letters to the Secretary of Health and Human Services (HHS), has fanned the flames of a growing controversy around the ethics of US government-sponsored trials seeking to prevent perinatal AIDS transmission in developing countries.

At issue is whether it is any longer justified to use placebo in these trials when an expensive but effective therapy has been found and is routinely used in women in industrialized countries.

On 23 October, Public Citizen, a Washington-based advocacy group, wrote to Donna Shalala, the HHS secretary, pointing out that researchers at the JHU School of Public Health in Baltimore, Maryland, had "tentatively" dropped plans for a placebo arm in an NIH-funded trial set to begin in Ethiopia as soon as February.
The trial, involving some 900 women, had originally proposed comparing short, less expensive regimens of an anti-AIDS drug, zidovudine (AZT), in pregnant women, against women given a placebo. The JHU researchers, Neal Halsey and Andrea Ruff, say that they have made "contingency plans" to modify the trial design by dropping the placebo arm "if other studies document the effectiveness of a practical short course regimen [of AZT] in a developing country".

The doctors at Public Citizen, Peter Lurie and Sidney Wolfe, jumped on this as evidence that the JHU researchers are "acknowledging that it is possible to conduct a scientifically valid and useful study without the use of a placebo arm". They demanded in their letter that Shalala immediately order US government-sponsored researchers "to stop any arm of their studies in which women are denied access to antiretroviral drugs, and to provide at least short-term
AZT for all women now getting a placebo."

The next day, the JHU researchers shot back a letter of their own to Shalala. "Our changes are not being made to accommodate any outside groups," they said. Rather it was in response to information expected early in 1998 from other United Nations and USsupported trials.

They accused Public Citizen of spreading "mistruths and distortions" in press releases and said Wolfe and Lurie "have deliberately misrepresented our position and actions in an attempt to undermine the ongoing trials" of AZT in developing countries. Wolfe, in turn, accused Ruff and Halsey of "cheap justifications of what they are doing."

A spokesman for Shalala, said on Saturday that Shalala would have no immediate response to the letters. But, he added "we're keenly aware of the ethical implications of these experiments and we are always looking at new information."

Meredith Wadman 